\title{
ANALISIS PERTUMBUHAN KINERJA KEUANGAN PT BANK MANDIRI (PERSERO) TBK
}

\author{
Hidayatullah \\ Jurusan Akuntansi, Fakultas Ekonomi dan Bisnis, Universitas Bina Nusantara \\ Jl. K.H. Syahdan No. 9, Palmerah, Jakarta Barat 11480 \\ scs_ais@yahoo.com
}

\begin{abstract}
This research was made with a view to assess and analyze financial performance of PT Bank Mandiri Tbk. The assessment was conducted by looking at the financial ratios of from 2003 until 2010, from the financial statements obtained from the website of Indonesian stock exchange, the value of the components of financial statements conducted re-calculation formula into the valuation ratios of the banking financial performance, then the results of are analysed per year. Conclusions from this analysis is compared with indicators of banking health assessment released by Bank Indonesia. Analysed financial ratios taken are among others CAR, NPL, $R O A$, and ROE. These are commonly used ratios by researchers in assessing the financial performance of banks.
\end{abstract}

Keywords: performance, CAR, NPL, LDR, ROA, ROE

\begin{abstract}
ABSTRAK
Penelitian ini dibuat dengan maksud untuk menilai dan menganalisis kinerja keuangan PT Bank Mandiri Tbk. Penilaian dilakukan dengan melihat rasio-rasio keuangan dari tahun 2003 hingga 2010, laporan keuangan diperoleh dari situs website Bursa Efek Indonesia, nilai komponen laporan keuangan dilakukan perhitungan ulang rumus ke dalam rasio penilaian kinerja keuangan perbankan, hasil dari masing-masing rasio keuangan dilakukan perbandingan dan analisis. Kesimpulan dari analisis dibandingkan dengan indikator penilaian kesehatan perbankan yang dirilis oleh Bank Indonesia. Rasi-Rasio Keuangan yang di analisis antara lain CAR, NPL, ROA,dan ROE. Rasio adalah yang paling banyak digunakan oleh para peneliti dalam menilai kinerja keuangan bank.
\end{abstract}

Kata kunci: kinerja, CAR, NPL, LDR, ROA, ROE 


\section{PENDAHULUAN}

\section{Latar Belakang}

Krisis keuangan global yang melanda dunia saat ini masih belum dapat diprediksi kapan akan berakhir dan kondisi ini akan lebih sulit lagi manakala perbankan masih tidak merasa percaya diri dalam menyalurkan kreditnya. Negara-negara seperti Indonesia, China, dan Brazil sebenarnya masih dapat bernafas lega karena permintaan pasar domestik masih cukup besar yang menciptakan pendapatan terbesar dari pasar domestik. Krisis keuangan global yang terjadi disebabkan oleh beberapa faktor, yaitu: (1) Membengkaknya aktivitas lindung nilai (hedging) yang dipakai untuk spekulasi; (2) Tingginya pertumbuhan kredit pada lembaga keuangan tanpa diiringi seleksi yang ketat terhadap calon debitur; dan (3) Pemberian kredit kepada anak perusahaan sendiri.

Namun karena negara-negara maju seperti Amerika Serikat, Inggris dan negara-negara eropa lainnya, Jepang dan Australia juga terkena imbas krisis, maka negara seperti Indonesia harus berhatihati, mengingat negara-negara maju tersebut memiliki peran yang yang sangat penting dalam perekonomian global. Negara yang memiliki ketergantungan terhadap ekspor akan terkena pukulan yang paling berat. Sebaliknya negara-negara yang trading ekspornya tidak besar terkena dampak krisis yang relatif ringan. Prediksi kedepan, perekonomian belum akan membaik, perkembangannya relatif akan jalan ditempat (flat) sampai setahun kedepan. Permasalahan negara-negara di Asia juga tidak akan jauh berbeda, yaitu tidak mengalami banyak perbaikan dalam kurun waktu setahun kedepan.

Dalam hal ini, bank yang unggul adalah bank yang mampu mengantisipasi segala kemungkinan yang terjadi, baik pada saat ekonomi sedang bagus maupun pada saat terjadi krisis ekonomi. Bank yang kuat adalah bank yang selalu siap dan waspada terhadap situasi krisis, tetap menciptakan peluang bisnis dan bersiap mendulang keuntungan saat keadaan finansial kembali membaik. Oleh sebab itu, perbankan agar tetap menyalurkan kredit meski kondisi ekonomi masih belum jelas. Apabila penyaluran kredit dihentikan, justru malah membuat situasi ekonomi dan bisnis menjadi kurang menguntungkan dan menyebabkan pertumbuhan ekonomi dalam negeri menjadi stagnan. Penyaluran kredit disaat perekonomian suatu negara tidak begitu stabil bukan tidak mengandung resiko buat bank itu sendiri jika bank juga kurang berhati-hati dalam melakukan pendanaan dalam bentuk pengucuran kredit kepada para kreditur bisa-bisa hal ini membuat dampak buruk pada kesehatan bank itu sendiri.

Di Indonesia sebagai negara juga memiliki banyak bank, tidak sedikit bank di indonesia mengalami kasus kebankrutan akibat kondisi ekonomi yang tidak menentu, yang segar di benak kita seperti kasus Bank Global dan Bank Century, meskipun kasus ini banyak yang mengatakan karena adanya unsur kecurangan yang sangat tinggi tetapi di lain hal kita juga tidak dapat mengabaikan bahwa kondisi ekonomi indonesia juga memiliki pengaruh yang cukup kuat. Berdasarkan latar belakang tersebut penulis ingin mengulang kembali penelitin yang sudah dilakukan banyak peneliti terdahulu yang berkaitan dengan kinerja perbankan, pada kesempatan ini peneliti ingin melakukan penelitian yang berkaitan dengan analisa kinerja keuangan pemerintah yang terdaftar di bursa efek Indonesia.

Masalah yang hendak diteliti ialah mengetahui kinerja keuangan PT Bank Mandiri Tbk dari tahun ke tahun, dan dilihat dari rata-rata CAR, mengetahui apakah kinerja PT Bank Mandiri Tbk dapat dikatakan baik menurut Peraturan Bank Indonesia tetang kecukupan modal bank umum. 


\section{Tinjauan Pustaka dan Penelitian sebelumnya}

Definisi bank adalah usaha yang menghimpun dana dari masyarakat dalam bentuk simpanan, dan menyalurkan kepada masyarakat dalam rangka meningkatkan taraf hidup rakyat banyak menurut Undang-undang No. 7 Tahun 1992 (dalam Supriyanti, 2008). Dengan kondisi perekonomian Indonesia yang naik turun sepertinya kita perlu melakukan analisa terhadap kinerja perbankan terutama bankbank milik pemerintah yang salah satunya merupakan PT Bank Mandiri Tbk. Kinerja keuangan bisa di lihat dari rasio-rasio keuangnnya seperti CAR, LDR, NPL, BO/PO dan NIM. Secara bersama-sama rasio-rasio keuangan tersebut mempunyai pengaruh yang sidnifikan terhadap kinerja keuangan perbankan (Prasetyo, 2006). Analisa rasio dapat menyikap hubungan dan sekaligus menjadi dasar perbandingan yang menunjukan kondisi atau kecendrungan yang tidak dapat di deteksi jika hanya melihat komponen-komponen rasio itu sendiri (Prastowo, 1995).

\section{Pengertian Tingkat Kesehatan Bank}

Secara sederhana dapat dikatakan bahwa bank yang sehat adalah bank yang dapat menjalankan fungsi-fungsinya dengan baik. Dengan kata lain, bank yang sehat adalah bank yang dapat menjaga dan memelihara kepercayaan masyarakat, dapat menjalankan fungsi intermediasi, dapat membantu kelancaran lalu lintas pembayaran serta dapat digunakan oleh pemerintah dalam melaksanakan berbagai kebijakannya, terutama kebijakan moneter. Dengan menjalankan fungsi-fungsi tersebut diharapkan dapat memberikan pelayanan yang baik kepada masyarakat serta bermanfaat bagi perekonomian secara keseluruhan. Untuk dapat menjalankan fungsinya dengan baik, bank harus mempunyai modal yang cukup, menjaga kualitas asetnya dengan baik, dikelola dengan baik dan dioperasikan berdasarkan prinsip kehati-hatian, menghasilkan keuntungan yang cukup untuk mempertahankan kelangsungan usahanya, serta memelihara likuiditasnya sehingga dapat memenuhi kewajibannya setiap saat. Selain itu, suatu bank harus senantiasa memenuhi berbagai ketentuan dan aturan yang telah ditetapkan, yang pada dasarnya berupa berbagai ketentuan yang mengacu pada prinsip-prinsip kehati-hatian di bidang perbankan.

\section{Return On Asset ( ROA )}

ROA merupakan salah satu rasio yang mengukur tingkat produktifitas dari aset perusahaan. ROA digunakan untuk mengetahui besarnya laba bersih yang dihasilkan perusahaan dengan menggunkan seluruh sumberdaya aset yang mereka miliki dalam aktivitas operasionalnya dalam rangka mencari laba. Tinggi rendahnya ROA tergangtung bagaimana manajemen mengelola seluruh asetnya, pengelolaan aset yang baik dan maksimal meneyebabkan tingkat ROA yang baik pula, ROA yang kurang baik mungkin di akibatkan banyak aset yang belum di kelola secara maksimal atau menganggur (Raharjo, 2005). Nilai ROA diperoleh dari cara membandingkan laba setelah pajak dengan total aset yang ada dalam perusahaan.

\section{Return On Equity (ROE)}

ROE merupakana rasio kemampuan perusahaan dalam menghasilkan Return dari investasi investor (Pemegang saham) atau dapat dikatakan sebarapa besar keuntungan yang diperoleh oleh para pemegang saham (Stockholders) (Brigham dalam Raharjo, 2005). Nilai ROE diperoleh dengan membandingkan nilai laba setelah pajak dengan jumlah modal sendiri perusahaan.

\section{Capital Adequacy Ratio (CAR)}

Berdasarkan Surat Edaran Bank Indonesia No 3/30 DPNP tanggal 14 Desember 2001. CAR merupakan perhitungan modal dan aktiva tertimbang menurut rasio dilakukan berdasarkan ketentuan kewajiban pernyedian modal minimum tertentu. CAR digunakan untuk mengukur permodalan yang 
ada untuk menutup kemungkinan kerugian dalam kegiatan perkreditan dan perdagangan surat-surat berharga (Prasetyo, 2006). Berdasarkan Peraturan Bank Indonesia No. 10/15/PBI/2008 tentang Kewajiban Penyedian Modal Minum Bank Umum mengatakan bahwa Bank memiliki kewajiban menyediakan modal sebesar 8\% dari Aset Tertimbang Menurut Resiko (ATMR) dan wajib menyediakan modal inti paling sedikit 5\% dari ATMR.

\section{Biaya Operasional/ Pendapatan Operasional (BO/PO)}

Rasio ini di gunakan untuk melihat perbandingan biaya operasi terhadap pendapatan operasi bank, semakin kecil angka rasio ini semakin baik kondisi bank dilihat dari perbandingan biaya terhadap pendapatnya. Perhitungan angka ini dilakukan perposisi tidak di setahunkan.

\section{Kualitas Aset}

Dalam kondisi normal sebagian besar aktiva suatu bank terdiri dari kredit dan aktiva lain yang dapat menghasilkan atau menjadi sumber pendapatan bagi bank, sehingga jenis aktiva tersebut sering disebut sebagai aktiva produktif. Dengan kata lain, aktiva produktif adalah penanaman dana Bank baik dalam rupiah maupun valuta asing dalam bentuk pembiayaan, piutang, surat berharga, penempatan, penyertaan modal, penyertaan modal sementara, komitmen dan kontijensi pada transaksi rekening administratif. Di dalam menganalisis suatu bank pada umumnya perhatian difokuskan pada kecukupan modal bank karena masalah solvensi memang penting. Namun demikian, menganalisis kualitas aktiva produktif secara cermat tidaklah kalah pentingnya. Kualitas aktiva produktif bank yang sangat jelek secara implisit akan menghapus modal bank. Walaupun secara riil bank memiliki modal yang cukup besar, apabila kualitas aktiva produktifnya sangat buruk dapat saja kondisi modalnya menjadi buruk pula. Hal ini antara lain terkait dengan berbagai permasalahan seperti pembentukan cadangan, penilaian asset, pemberian pinjaman kepada pihak terkait, dan sebagainya

\section{Kredit Bermasalah (NPL)}

Berdasarkan Surat Edaran Bank Indonesia No 3/30 DPNP tanggal 14 Desember 2001. Pengertian dari kredit merupakan kredit yang di berikan kepada pihak ketiga (tidak termasuk kredit yang di berikan kepada bank lain). Kredit bermasalah adalah kredit dengan kualitas kurang lancar, diragukan atau macet. Kredit bermasalah di hitung secara gross tidak dikurangi dengan PPAP (Penyisihan Pengahapusan Aktiva Produktif), angka di hitung perposrsi tidak disetahunkan.

\section{METODE}

Jenis data yang digunakan dalam penelitian ini adalah data sekunder berupa laporan keuangan Bank Mandiri Tbk. Sumber data yang digunakan adalah laporan keuangan berupa neraca dan laporan laba / rugi tahun 2003 sampai dengan tahun 2010. Dalam penelitian ini Indikator yang digunakan untuk menilai kinerja bank adalah rasio keuangan yang terdiri dari rasio rentabilitas, rasio likuiditas dan tingkat kecukupan modalnya. Rasio rentabilitas terdiri dari Return On Asset dan Return On Equity, dan rasio likuiditas dan juga Capital Adequacy Ratio (CAR).

Return On Asset adalah kemampuan perbankan untuk memperoleh laba atas sejumlah asset yang dimiliki oleh Bank. Return On Asset dapat diperoleh dengan cara menghitung rasio antara laba setelah pajak dengan total aktiva.

ROA = Laba Sebelum Pajak Disetahunkan/ Rata-rata Total Aset

(Sesuai dengan SE No.6/23/DPNP tanggal 31 Mei 2004) 
Return On Equity adalah indikator kemampuan perbankan dalam mengelola modal yang tersedia untuk memperoleh laba bersih. ROE dapat diperoleh dengan menghitung rasio antara laba setelah pajak dengan Total Equitas.

$$
\text { ROE }=\text { Laba sebelum pajak / Total modal }
$$

Loan to Deposit Ratio adalah indikator kemampuan perbankan dalam membayar semua dana masyarakat dan modal sendiri dengan mengandalkan kredit yang didistribusikan kepada masyarakat. LDR dapat diperoleh dengan cara menghitung rasio antara Total Loan dengan Total Deposit.

$$
\begin{aligned}
& \text { LDR = Total kredit } /(\text { Penghimpunan dana + Modal Inti) } \\
& \text { (Sesuai dengan SE No.6/23/DPNP tanggal } 31 \text { Mei 2004) }
\end{aligned}
$$

Penghimpunan dana terdiri dari simpanan pihak ketiga, Bank Indonesia, ABP lebih dari 3 Bulan, pinjaman yang diterima lainnya lebih dari 3 bulan dan modal pinjaman.

Capital Adequacy Ratio (CAR) adalah rasio yang memperlihatkan seberapa besar jumlah seluruh aktiva bank yang mengandung resiko (kredit, penyertaan, surat berharga, tagihan pada bank lain) dibiayai dari modal sendiri, disamping dana-dana dari sumber-sumber diluar bank.

$$
\begin{gathered}
\text { CAR = Modal Bank } / \text { Total ATMR } \\
(\text { sesuai dengan PBI No.10/15/PBI/2008) }
\end{gathered}
$$

Modal Bank bagi yang berkantor pusat di Indonesia antara lain Modal Inti, Modal Pelengkap, dan Modal Pelengkap Tambahan.

Evaluasi kinerja dari penelitian ini dengan cara melihat pergerakan dari trend rasio kinerja keuangan selama delapan tahun operasional,menganalisa kenaikan dan penurunan masing-masing indikator tersebut.

\section{HASIL DAN PEMBAHASAN}

Dari berdasarkan olah data dan perhitungan dapat dirangkum menjadi informasi rasio yang tergambar dalam delapan tahun analisis penelitian ini seperti terlihat pada Tabel 1 pada Lampiran. Pada Tabel 1 tersebut dapat kita lihat kenaikan dan penurunan dari masing-masing indikator kinerja

\begin{tabular}{|c|c|c|c|c|c|c|c|c|c|c|c|c|c|c|c|c|c|}
\hline No. & $\begin{array}{c}\text { Rasio } \\
\text { Keuangan }\end{array}$ & 2003 & $\begin{array}{l}\text { Naik (+) } \\
\text { Turun }(-)\end{array}$ & 2004 & $\begin{array}{l}\text { Naik (+) } \\
\text { Turun }(-)\end{array}$ & 2005 & $\begin{array}{l}\text { Naik (+) } \\
\text { Turun }(-)\end{array}$ & 2006 & $\begin{array}{l}\text { Naik (+) } \\
\text { Turun }(-)\end{array}$ & 2007 & $\begin{array}{l}\text { Naik (+) } \\
\text { Turun }(-)\end{array}$ & 2008 & $\begin{array}{l}\text { Naik }(+) \\
\text { Turun }(-)\end{array}$ & 2009 & $\begin{array}{l}\text { Naik }(+) \\
\text { Turun }(-)\end{array}$ & 2010 & $\begin{array}{l}\text { RATA- } \\
\text { RATA }\end{array}$ \\
\hline 1 & ROA & $2.80 \%$ & $0.30 \%$ & $3.10 \%$ & $-2.60 \%$ & $0.50 \%$ & $0.60 \%$ & $1.10 \%$ & $1.20 \%$ & $2.30 \%$ & $0.20 \%$ & $2.50 \%$ & $0.50 \%$ & $3.00 \%$ & $0.40 \%$ & $3.40 \%$ & $2,34 \%$ \\
\hline 2 & ROE & $23.60 \%$ & $-0.80 \%$ & $22.80 \%$ & $-20.30 \%$ & $2.50 \%$ & 7.5096 & $10.00 \%$ & $5.80 \%$ & $15.80 \%$ & 2.3096 & $18.10 \%$ & $4.00 \%$ & $22.10 \%$ & $2.30 \%$ & $24.40 \%$ & $17,41 \%$ \\
\hline 3 & NPL & $139.10 \%$ & $-10.30 \%$ & $128.80 \%$ & $-84.80 \%$ & $44.00 \%$ & $30.80 \%$ & $74.80 \%$ & $34.20 \%$ & $109.00 \%$ & $18.10 \%$ & $127.10 \%$ & $73.30 \%$ & $200.40 \%$ & $-8.00 \%$ & $192.40 \%$ & $126,95 \%$ \\
\hline 4 & LDR & $42.50 \%$ & $11.20 \%$ & $53.70 \%$ & $-2.00 \%$ & $51.70 \%$ & $5.55 \%$ & $57.25 \%$ & $-2.95 \%$ & $54.30 \%$ & $4.90 \%$ & $59.20 \%$ & $2.20 \%$ & $61.40 \%$ & $6.20 \% 6$ & $67.60 \%$ & $55,96 \%$ \\
\hline 5 & CAR & $27.70 \%$ & $-2.40 \%$ & $25.30 \%$ & $-1.60 \%$ & $23.70 \% 6$ & $1.60 \%$ & $25.30 \%$ & $-4.20 \%$ & $21.10 \%$ & $-5.40 \%$ & $15.70 \%$ & $-0.10 \%$ & $15.60 \%$ & $-0.90 \%$ & $14.70 \%$ & $21,14 \%$ \\
\hline 6 & NI (Milliar) & 4.586 & 670 & 5.256 & $(4.653)$ & 603 & 1.818 & 2.421 & 1.925 & 4.346 & 967 & 5.313 & 1.842 & 7.155 & 2.063 & 9.218 & 4.862 \\
\hline
\end{tabular}
PT Bank Mandiri seperti ROA,ROE,NPL,LDR,CAR dan Net Income (NI), mulai tahun 2003 sampai dengan tahun 2010. Dari setiap indikator memiliki trend secara kuatitatif berbeda-beda, hal ini di pengaruhi oleh faktor-faktor dan komponen dari penusun indikator tersebut.

Tabel 1 : Rekapitulasi Perhitungan Rasio-Rasio Kinerja Keuangan 


\section{Return on Asset}

Gambar 1 dibawah ini menunjukkan secara parsial indikator kinerja Return On Asset

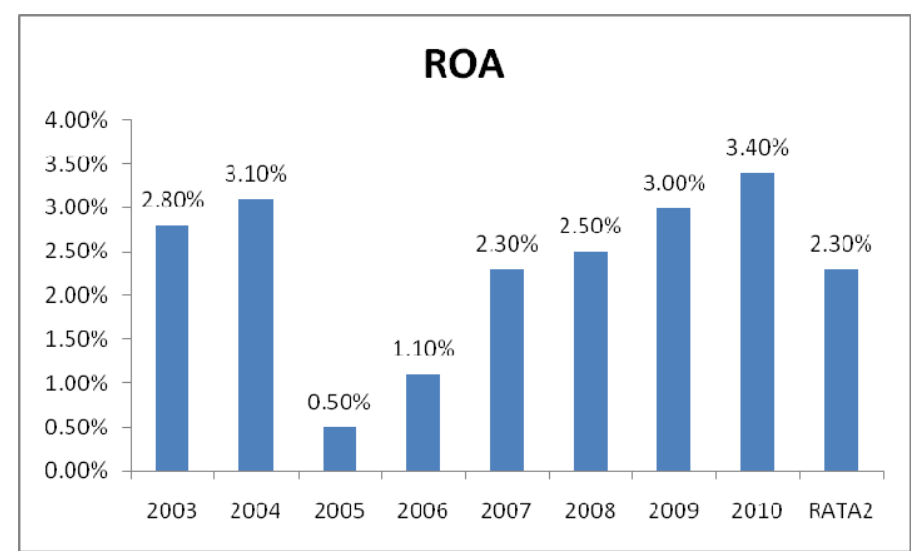

Gambar 1. Indikator Kinerja Return on Assets

PT Bank Mandiri (Persero) Tbk 2003-2010

ROA pada tahun 2004 mengalami peningkatan sebesar 0,30\% dari tahun 2003 kemudian mengalami penurunan pada tahun 2005 sebesar 2,60\%, kemudian tahun - tahun berikutnya hingga tahun 2010 kembali mengalami kenaikan sebesar 0,40\%, kemudian ratarata ROA selama delapan tahaun sebesar 2,34\% dan rata-rata kenaiknnya sebesar 0,08\%. Disini terlihat rata-rata kenaikan ROA masih jauh di bawah rata-rata peningkatan ROA-nya, hal ini di karenakan pada tahun 2005 ROA PT Bank Mandiri merosot jauh dari 3,10\% pada tahun 2004 menjadi 0,50\% pada tahun 2005.

\section{Return on Equity}

Gambar 2 menunjukkan secara parsial indikator kinerja Return on Equity.

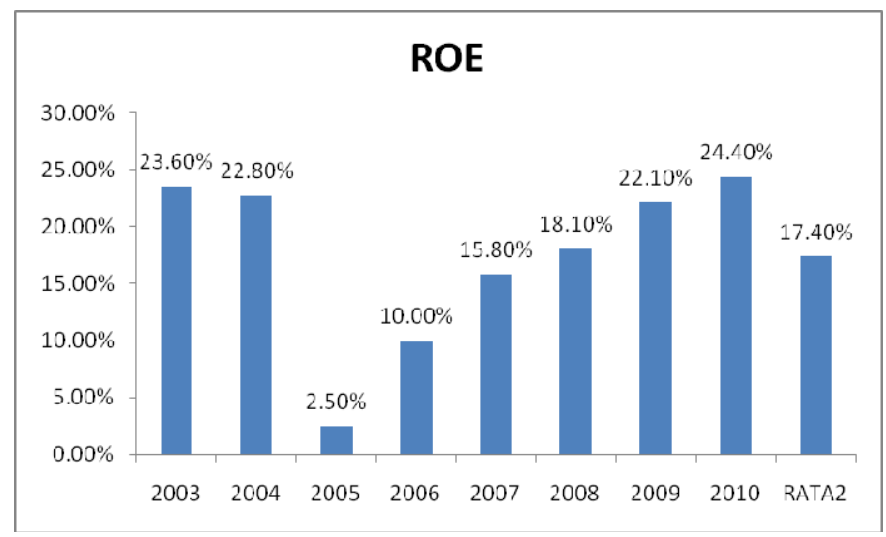

Gambar 2. Indikator Kinerja Return on Equity PT Bank Mandiri (Persero) Tbk 2003-2010

Pada tahun 2004 ROE PT Bank Mandiri mengalami penurunan sebesar 0,80\%, dan kemudian di tahun berikutnya turun lagi sebesar 20,30\% di tahun 2005. Pada tahun 2006 kembali mulai naik 
sebesar 7,50\% dan terus naik sampai pada tahun 2010 sebesar 2,30\%. Rata-rata ROE selama delapan tahun sebesar $17,41 \%$ dan rata-rata kenaikan ROE-nya sebesar 0,10\%, hal ini di karenakan ROE-nya merosot jauh pada tahun 2005.

\section{Non Performing Loans}

Gambar 3 menunjukkan secara parsial indikator kinerja Non Performing Loan.

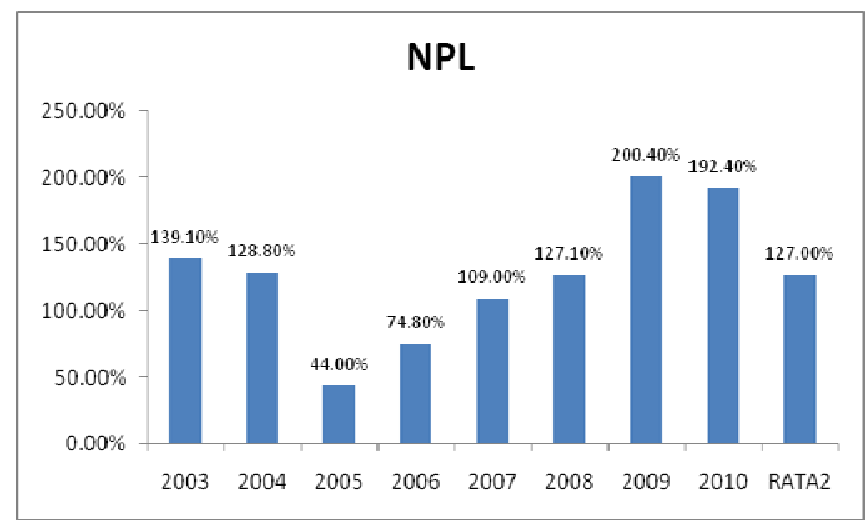

Gambar 3. Indikator Kinerja Non Performing Loan PT Bank Mandiri (Persero) Tbk 2003-2010

Pada tahun 2004 NPL PT Bank Mandiri mengalami penurunan sebesar 10,30\% kemudian tahun berikutnya juga turun sebesar $84,80 \%$ tahun 2005 , penurunan yang sangat signifikan kemudian pada tahun 2006 mulai mengalami peningkatan kembali sebesar 30,80\% samapai dengan pada tahun 2009 sebesar 73,30\% dan turun kembali pada tahun 2010 sebesar 8\%. Rata-rata NPL selama delapan tahun sebesar 126,95\%. Dan rata-rata kainakannya sebesar 6,66\%. Hal ini disebabkan oleh penurunan yang sangat signifikan pada tahun 2005 dari 128,80\% pada tahun 2004 menjadi 44\% pada tahun 2005 .

\section{Loan to Deposit Rasio}

Gambar 4 menunjukkan secara parsial indikator kinerja Loan to Deposit Ratio.

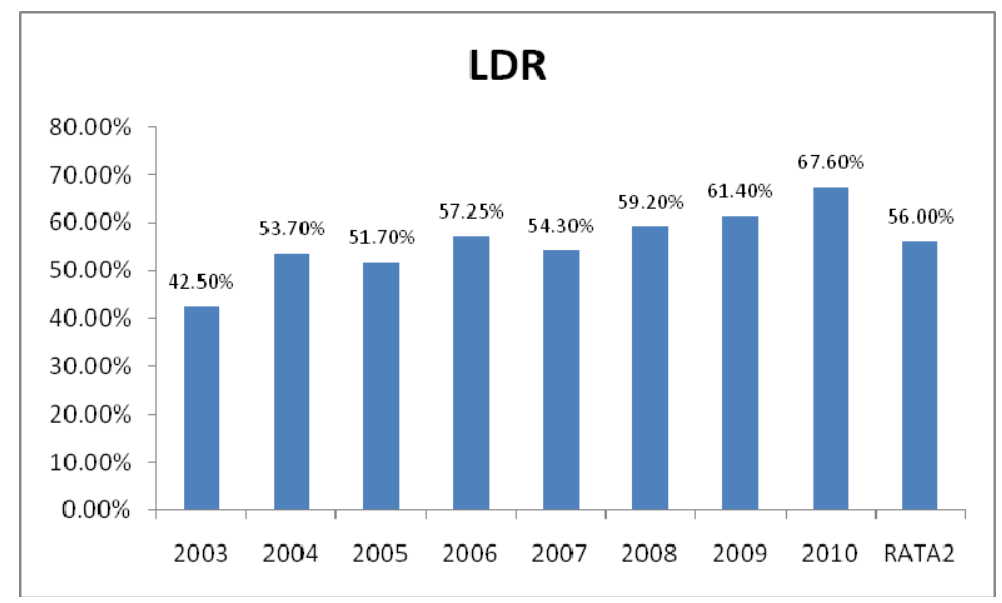

Gambar 4. Indikator Kinerja Loan to Deposit Ratio PT Bank Mandiri (Persero) Tbk 2003-2010 
Pada tahun 2004 LDR-nya meningkat sebesar 11,20\% kemudian di tahun 2005 turun sebesar 2\%, setelah itu naik kembali sebesar 5,55\% di tahun 2006. Sampai tahun 2010 terus mengalami naik turun, pada tahun 2010 naik sebesar 6,20\%. Rata -rata LDR selama 8 tahun sebesar 55,96\% dan ratarata kenaikan LDR-nya sebesar 3,14\%.

\section{Capital Adequacy Ratio}

Gambar 5 menunjukkan secara parsial indikator kinerja Capital Adequacy Ratio.

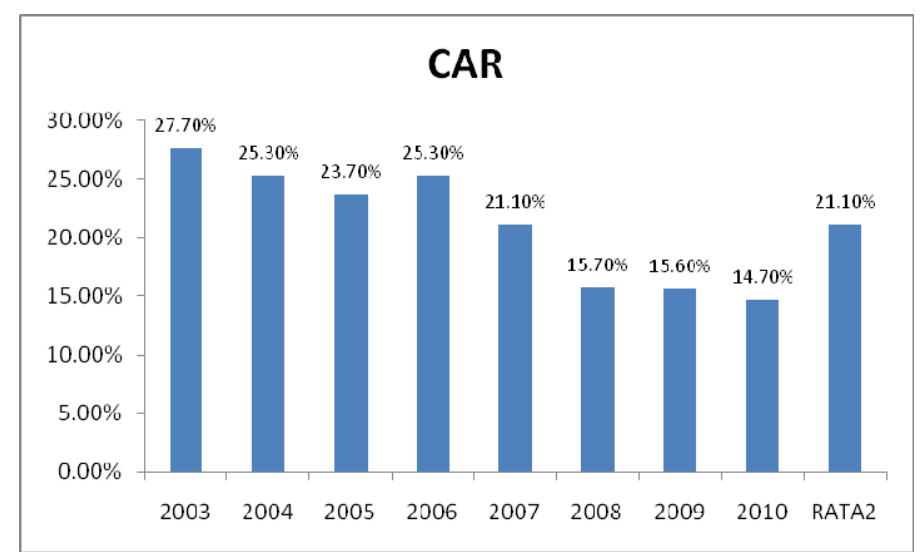

Gambar 5. Indikator Kinerja Capital Adequacy Ratio

PT Bank Mandiri (Persero) Tbk 2003-2010

CAR PT Bank Mandiri Tbk pada tahun 2004 turun sebesar 2,40\% dari tahun 2003 sebesar $27,70 \%$, kemudian tahun berikutnya juga mengalami penurunan sebesar $1,60 \%$ pada tahun 2005 , kemudian di imbangi dengan kenaikan sebesar 1,60\% pada tahaun 2006. Lalu turun kembali pada tahun 2007 sampai dengan 2010 turun sebesar 0,90\% dari tahun 2009 sebesar 15.60\%. Rata-rata CARnya selama 8 tahun sebesar 21,14\% dan rata-rata penurunannya sebesar 1,63\%. Rata-rata CAR PT Bank Mandiri Tbk masih di atas kewajiban penyedian modal minimum bank umum yang di syaratkan Peraturan Bank Indonesia No.10/15/PBI/2008 sebesar 8\% dan wajib menyediakan modal inti paling sedikit 5\% dari ATMR.

\section{Net Income}

Gambar 6 menunjukkan secara parsial indikator kinerja Net Income.

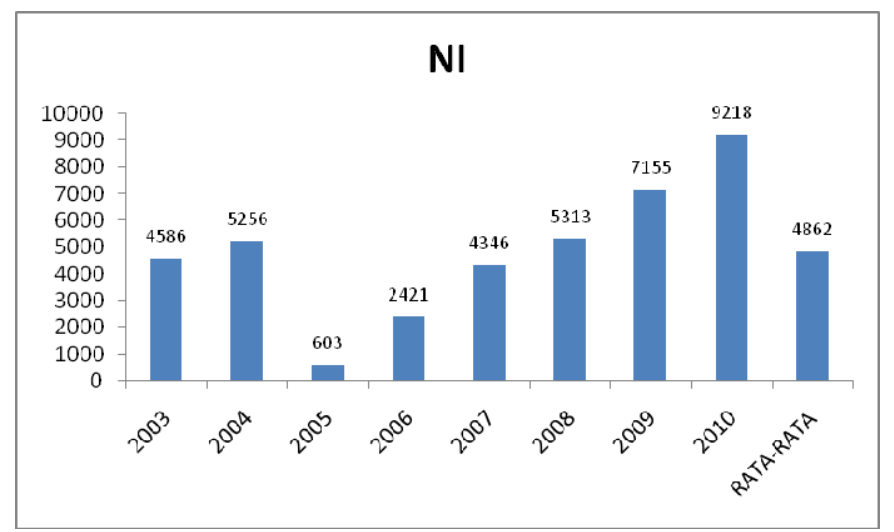

Gambar 6. Indikator Kinerja Net Income

PT Bank Mandiri (Persero) Tbk 2003-2010 
Pada tahun 2004 pendapatan bersih bank mandiri meningkat sebesar Rp 670 miliyar tetapi pada tahun 2005 merosot jauh turun sebesar Rp 4,6 Triliun kemudian tahun 2006 meningkat kembali sebesar Rp 1,8 triliun, tahun 2007 meningkat Rp 1,9 triliun, tahun 2008 maningkat Rp 967 miliar, tahun 2009 meningkat sebesar Rp 1,8 triliun dan tahun 2010 meningkat sebesar Rp, 2,06 Triliun. Rata-rata laba bersih pertahun sebesar Rp 4,86 triliun, dan rata-rata peningkatan laba sebesar Rp 579 miliar.

\section{PENUTUP}

Dari sisi Analisis ROA,ROE, dan NI terdapat peningkatan kinerja PT Bank Mandiri Tbk dari tahun 2003 sampai dengan 2010. Meskipun rata-rata dari NPL juga meningkat dan rata-rata dari CARturun, tetapi nilai CAR-nya masih jauh diatas yang di syaratkan Peraturan Bank Indonesia. Sepanjang tahun pengamatan dari tahun 2003 samapai dengan tahun 2010, tahun 2005 merupakan tahun dimana kinerja PT Bank Mandiri Tbk paling merosot di banding tahun-tahun yang lain, hal ini dikarenakan ROA,ROE,NI turun sangat signifikan. Dari sisi kecukupan modal atau CAR maka tahun 2007 adalah yang paling buruk karena CAR-nya 5,4 \% dari tahun sebelumnya. Dari semua indikator penilaian tahun 2010 merupakan tahun dengan kinerja terbaik PT Bank Mandiri Tbk di banding tahun-tahun sebelumnya. Rata-rata CAR PT Bank Mandiri Tbk selama 8 tahun pengamatan sebesar 21,14\% ini jauh 9,14\% diatas ketentuan dalam Peraturan Bank Indonesia No.10/15/PBI/2008 yang mensyaratkan minimal $12 \%$ terdiri dari $8 \%$ penyedian modal minimum dan $5 \%$ penyedian modal inti minimum dari ATMR.

\section{Saran}

Penelitian ini hanya memilih satu bank dengan banyak tahun operasional yaitu PT Bank Mandiri Tbk, sebenarnya bisa dilakukan atau di bandingkan dengan bank-bank sejenis yang bisa dilakukan dalam penelitian selanjutnya. Penelitian ini juga tidak membatasi dan mengelompokkan tahun sebelum dan setelah krisis moneter dimana dampak itu saingan berpengaruh pada kinerja perbankan secara keseluruhan. Mungkin peneliti selanjutnya bisa lebih memperhatikan dan memfokusukan pada kondisi tersebut.

\section{DAFTAR PUSTAKA}

Bank Indonesia (2001). Surat Edaran Bank Indonesia No 3/30 DPNP tanggal 14 Desember 2001 tentang laporan keuangan publikasi triwulanan dan bulanan bank umum serta laporan tertentu yang disampaikan kepada bank indonesia. Jakarta: Direktorat Penelitian Dan Pengaturan Perbankan, Bank Indonesia

Bank Indonesia (2004). Surat edaran untuk semua bank umum yang melaksanakan kegiatan usaha secara konvensional di indonesia No.6/23 DPNP tanggal 31 mei 2004 tentang sistem penilaian tingkat kesehatan bank umum. Jakarta: Bank Indonesia

Bank Indonesia. (2008). Peraturan Bank Indonesia No.10/15/PBI/2008 Tentang Kewajiban Penyediaan Modal Minimum Bank Umum. Lembaran Negara Republik Indonesia Tahun 2008 Nomor 135. Jakarta: Bank Indonesia .

Bank Indonesia. (2010). Statistik Perbankan Indonesia. Jakarta: Bank Indonesia. 
Bursa Efek Indonesia. (2011). Laporan Keuangan \& Tahunan. Diambil kembali dari Indonesia Stock Exchange: http://www.idx.co.id

Prasetyo, W. (2006). Pengaruh Rasio CAMEL Terhadap Kinerja Keuangan Pada Bank. Skripsi.Tidak dipublikasikan, Universitas Islam Indonesia.

Prastowo, D. (1995). Analisis Laporan Keuangan. UPP AMP YKPN. Yogyakarta.

Raharjo, S. (2005). Analisa Pengaruh Kinerja Keuangan Terhadap Return Saham Pada Perusahaan LQ-45 di Bursa Efek Jakarta. Skripsi. Tidak dipublikasikan. Universitas Islam Indonesia.

Supriyanti, N. (2008). Analisa Pengaruh Inflasi dan Suku Bunga BI Terhadap Kinerja Keuangan PT Bank Mandiri.Tbk Berdasarkan Rasio Keuang . Skripsi, tidak dipublikasikan, Universitas Gunadarma . 